Jurnal Ilmiah

PELA SEBAGAI SARANA PENYELESAIAN KONFLIK ANTARA SUKU ALUNE DAN WEMALE

DI KABUPATEN SERAM BAGIAN BARAT PROPINSI MALUKU

(Suatu Kajian Hukum Adat)

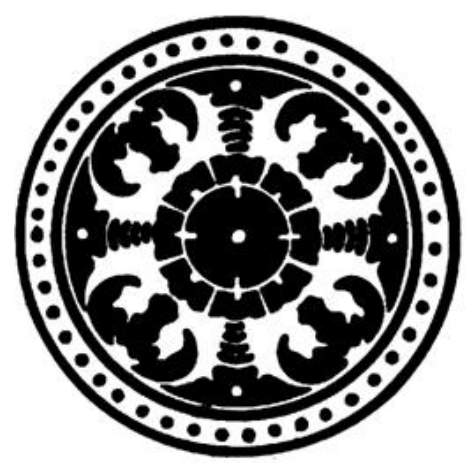

Steven Makaruku

HUKUM PIDANA

PROGRAM PASCASARJANA

MAGISTER ILMU HUKUM

UNIVERSITAS UDAYANA

DENPASAR

2012 


\title{
PELA SEBAGAI SARANA PENYELESAIAN KONFLIK \\ ANTARA SUKU ALUNE DAN WEMALE \\ DI KABUPATEN SERAM BAGIAN BARAT PROPINSI MALUKU
}

(Suatu Kajian Hukum Adat)

Oleh :

Steven Makaruku, SH

\begin{abstract}
Research about "Pela" as faulity solution conflict berween villages on Tribe Alune and Wemale in district Kairatu, Wets Seram, with aim to giving description all at once input for peoples. Gevernment and sympathy of law in this area about important Constribution Pela on regulatury living people.

This research do that on four village whose have design relation its clear, that is : village Tihulale with village Hukuanakota and village Rambatu with Village Abio. The Research Object head of people, Figure Customs, Figure of peoples and people member.

The method of research characteristic is descriptive analyse and analyse of data do qualitative. From analyse product have a concluded that "Angkat Pela and Panas Pela" to make resemble two faulity important which until now. This enough to give Constribution whose to signify for people a finished several conflict which rise. From "Angkat Pela and Panas Pela" the people can find conscious self to always look after, to make care and system of life that fixed, save and peace.
\end{abstract}

\section{Key Words : Pela, Constribution, Conflict}

\section{PENDAHULUAN}

Dalam menelaah hukum, kita akan menjumpai hukum positif, yaitu hukum yang berlaku di suatu negara dan pada suatu waktu yang tertentu. Hukum itu bersumber pada undang-undang, kebiasaan-kebiasaan dan perjanjianperjanjian.

Hukum sebagaimana dalam konteks di atas, tidak bisa dilepaskan dari sistem hukum di Indonesia. Indonesia yang menganut Negara hukum yang demokratis berdasarkan Pancasila dan UndangUndang Dasar 1945 yang secara konstitusional mengakui ketiga bentuk sumber hukum tersebut. Baik tertulis maupun hukum tidak tertulis, keduanya memiliki peranan yang sangat besar bagi terciptanya ketertiban dan keamanan dalam masyarakat, sekaligus merupakan landasan bagi pelaksanaan hukum di Indonesia.

Berkenaan dengan konsepsi hukum yang demikian, maka hukum tidak hanya dilihat sebatas rumusan yuridis, tetapi lebih dari itu harus dilihat pula berbagai norma hukum yang hidup dan berlaku dalam masyarakat yang keseluruhannya tercakup dalam hukum adat. Hukum adat sebagai hukum yang tidak tertulis merupakan suatu kompleks norma-norma yang bersumber 
pada perasaan keadilan rakyat yang selalu berkembang serta meliputi peraturan tingkah laku manusia dalam kehidupan sehari-hari dalam masyarakat, sebagian besar tidak tertulis, senantiasa ditaati dan dihormati oleh masyarakat karena mempunyai akibat hukum atau sanksi ${ }^{1}$.

Lebih jelas bahwa tiap-tiap hukum merupakan suatu sistem yaitu peraturanperaturannya merupakan suatu kebulatan berdasarkan atas kesatuan alam pikiran, begitupun hukum adat ${ }^{2}$.

Indonesia yang terdiri dari beriburibu pulau yang terbentang dari Sabang sampai Merauke, mempunyai adat istiadat yang berbeda-beda pada masing-masing daerah. Wilayah hukum adat Indonesia terbagi dalam 19 lingkungan hukum adat. Dimana dalam hukum adat tiap-tiap lingkungan hukum adat itu memiliki ciri khas yang memberikan tanda kenal pada hukum adat yang bersangkutan sehingga mempermudah indentitasnya.

Maluku khususnya di Pulau Ambon, Pulau-pulau Lease dan Pulau Seram terdapat salah satu lembaga adat yang sampai saat ini masih tetap dipertahankan dalam kehidupan masyarakat, yakni "Ikatan Pela". Istilah Pela dalan kenyataanya menunjuk pada ikatan kesatuan dan persaudaraan antara dua atau lebih negeri, baik itu antara

\footnotetext{
${ }^{1}$ Mahadi, Monografi Hukum Adat, Binacipta , h.13.

${ }^{2}$ Soejomo Soekanto, Pokok-pokok Sosiologi Hukum
}

negeri-negeri Kristen atau antara negerinegeri Islam maupun negeri-negeri Islam dan Kristen. ${ }^{3}$

Hubungan Pela yaitu hubungan yang terjalin antara dua negeri atau desa yang terbentuk karena suatu latar belakang historis. Latar belakang historis dimaksud bisa terjadi karena yang satu membantu yang lain dalam kepentingan negeri atau desa secara menyeluruh. Selain itu pela juga merupakan salah satu cara penyelesaian perkara antar dua negeri yang bermusuhan maka diangkatlah pela. ${ }^{4}$

Konsekuensi dari pengangkatan pela tersebut menimbulkan akibat hukum (sanksi) bagi kedua belah pihak yang terikat hubungan pela, karena ada dalam hubungan pela tersebut, perjanjianperjanjian tertentu berupa laranganlarangan atau pantangan yang tidak boleh dilanggar. Pelanggaran terhadap laranganlarangan tersebut akan dikenakan sanksi.

Bila dilihat bentuknya maka hubungan pela dalam kenyataannya memiliki kerakteristik yang berbeda-beda tergantung dari latarbelakan sejarah yang dimiliki oleh negeri-negeri atau desa-desa yang berpela. Dari jenisnya maka pela pada hakekatnya diklasifikasikan kedalam dua jenis yaitu : "Pela Batu Karang atau Pela Minum Darah dan Pela Tempat Sirih.

\footnotetext{
${ }^{3}$ Pieter Tanamal, Pengabdian dan Perjuangan, h.18

4 Anonymous, 1989, Tata Pergaulan di Lingkungan Pergaulan Keluarga dan Masyarakat Daerah Maluku, Departemen Pendidikan dan Kebudayaan, h. 74.
} 
Jenis hubungan pela sebagaimana disinggung diatas telah ada berabad-abad dan berjalan secara turun-temurun mulai dari zaman datuk-datuk sampai ke generasi sekarang ini. Sampai kini kekuatan pela itu tetap ada dan mengikat negeri-negeri atau desa-desa di Maluku tanpa mengenal atau mempersoalkan batas suku, mata rumah, negeri dan agama.

Hubungan pela ini juga dikenal pada desa-desa dalam suku Alune dan suku Wemale di Kecamatan Kariatu Kabupaten Seram Bagian Barat yang perkembangannya berjalan sesuai dengan tatanan nilai dan norma yang berlaku dalam masyarakat. Dari segi sejarah dapat dijelaskan bahwa hubungan pela antara desa-desa dalam suku Alune dan suku Wemale memiliki ikatan sebagai hubungan Pela Darah dan hubungan Pela Tempat Sirih, dimana terjadinya hubungan pela ini karena latar belakang pembunuhan. Satusatunya jalan untuk menyelesaikan konflik dan mewujudkan suatu perdamaian dan ketertiban serta ketentraman dalam masyarakat, maka kedua belah pihak sepakat untuk mengangkat pela.

$$
\text { Sebagai ilustrasi dapat }
$$
digambarkan bahwa pela merupakan bangunan bahwa dari moral individu dan masyarakat. Pela dapat dikatakan sebagai sumber nilai dan moral yang mengilhami dan mengikat negeri-negeri dan desa-desa yang berpela. Moral ini apabila dilaksanakan secara baik dan teratur merupakan sumber solidaritas, sebaliknya bila salah digunakan akan mengarah kepada hal imperative yaitu tindakantindakan yang dapat mengakibatkan hukuman atau sanksi kepada sesama pela itu sendiri baik dari manusia secara adat maupun hukuman dari Tuhan Sang Pencipta. Hal inilah yang menarik perhatian penulis untuk merumuskan permasalahan pokok, yaitu : "bagaimana kontribusi pela sebagai sarana penyelesaian konflik antara desa-desa dalam suku Alune dan suku Wemale di Kecamatan Kairatu Kabupaten Seram Bagian Barat".

Tujuan umum dari penelitian ini adalah untuk menemukan kontribusi pela sebagai sarana penyelesaian konflik. Tujuan khusus dari penelitian ini adalah untuk meneliti dan mendeskripsikan kontribusi pela sebagai sarana penyelesaian konflik.

Manfaat dari penelitian ini diharapkan dapat memberikan gambaran sekaligus masukan bagi masyarakat, pemerintah dan pemerhati hukum di daerah ini tentang pentingnya pela sebagai sarana penyelesaian konflik.

\section{Metode Penelitian}

Penelitian ini dilakukan pada empat desa di Kecamatan Kairatu yang dianggap berpela, yaitu desa Abio, desa Rambatu, 
desa Hukuanakota dan desa Tihulale. desadesa ini di pilih untuk mewakili desa-desa Alune dan desa-desa Wemale di Kabupaten Seram Bagian Barat, karena memiliki status hubungan pela dan suku yang jelas.

Data yang diperlukan dalam penelitian ini adalah data primer dan data sekunder. Data primer diperoleh melalui wawancara langsung dengan kepala-kepala desa, tokoh-tokoh masyarakat dan anggota masyarakat yang dijadikan sampel, dengan menggunakan daftar pertanyaan terstruktur (Kuisioner), sedangkan data sekunder diperoleh dari wawancara (depth interview) dengan tokoh-tokoh adat setempat serta bahan kajian sumber pustaka lainnya.

Metode analisa yang di pergunakan dalam penelitian ini adalah deskriptif, dan analisa data dilakukan secara kualitatif yang bertujuan untuk menggambarkan keadaan koresponden sesuai dengan yang nyata di lapangan.

\section{Hasil dan Pembahasan}

\section{A. Kontribusi Pela}

Adat istiadat suatu tempat merupakan norma-norma yang berlaku sepanjang masa dan diwariskan sacara turun temurun, sehingga adat merupakan sesuatu yang harus dipatuhi dalam menyelenggarakan kepentingan bersama. Melalui adat orang dari generasi ke generasi melihat keberadaannya tereksiter pada menjaga dan memelihara keberadaannya.

Manusia yang diikat oleh adat adalah manusia yang dibenarkan oleh adat. Kalau segala sesuatu yang ia lakukan, perkatakan dan pikirkan sesuai dengan adat, maka ia (orang yang bersangkutan) dibenarkan oleh adat. Ia merasa tentram dan selebihnya akan diterima oleh anggota masyarakat, bilamana ia hidup sesuai adat. Dengan kata lain seseorang memiliki tempat yang aman, terjamin, terlindung didalam masyarakat bilamana ia mau diatur oleh adat yang berlaku. Setiap orang yang baru lahir kemudian dibesarkan serta hidup terus-menerus di dalam masyarakat yang hanya adat, ia akan berpendapat bahwa hidup sesuai adat adalah yang terbaik, sebaliknya hidup tidak sesuai dengan adat akan mendatangkan malapetaka bagi dirinya dan juga bagi masyarakat pada umumnya. Aturan-aturan yang terdapat dalam adat itu seolah-olah berada di luar daripada individu yang menjadi warga dalam persekutuan adat tersebut. Sejak kecil mereka telah diresapi dengan aturan yang hidup dalam masyarakat, sehingga konsepsi ini telah lama berakar dalam jiwa mereka.

Salah satu lembaga adat yang masih dipertahankan dalam kehidupan masyarakat Maluku, khususnya di Ambon dan pulau-pulau Lease serta di Pulau 
Seram adalah ikatan pela. Pela seperti yang dikenal dalam masyarakat adat Maluku sekarang ini adalah suatu ikatan persaudaraan yang telah melembaga antara penduduk dari dua desa atau lebih baik antara desa-desa Islam maupun antara desa Kristen dan desa Islam. Ikatan tersebut telah dibentuk oleh para leluhur (tetenenek moyang) dalam suatu keadaan khusus, serta memikul hak dan kewajiban yang terlihat dalam ikatan tersebut. ${ }^{5}$

Pela sebagai suatu bagian dari adat, memiliki seperangkat aturan yang mengikat masing-masing pribadi dalam persekutuan tersebut. Aturan ini dipahami sebagai yang berasal dari tete-nenek moyang yang memiliki kuasa, kekuatan tertentu yang tidak dapat dikuasai dan dikehendaki oleh manusia, suatu kuasa yang dianggap trasenden. Trasenden kuasa tete-nenek moyang (para leluhur) itu mengakibatkan manusia mempercayainya, sehingga pada gilirannya merupakan suatu kepercayaan. Dengan demikian nilai-nilai pela sebagian besar bersumber dari kepercayaan agama asli dan merupakan nilai-nilai yang bersifat religius. Hal pokok yang perlu dikemukakan disini adalah pela bukanlah agama tetapi dalam ikatan pela itu terkandung nilai-nilai agamawi yang berkaitan dengan kepercayaan kepada Tuhan sang pencipta dan para leluhur (tetenenek moyang) sebagai yang mengatur kehidupan manusia.

\footnotetext{
${ }^{5}$ F.L Cooley, 1902, Altar and Thome in Central Molucan Societies, Yale University, h, 261.
}

Adat pela yang merupakan suatu sistem nilai yang bersifat religius itu perlu ditaati agar fakta pela itu tetap hidup. Peraturan-peraturan dan hukum adat itu memiliki dua sifat sekaligus yaitu pertama ; yuridis (hukum) yang mengatur relasi antara individu yang terlibat dalam ikatan pela tersebut. Pelanggaran terhadap adat pela diadili dan dihukum oleh penguasa adat (Badan Saniri Negeri) dengan jenis hukuman badan dan lain-lain. Kedua ; sifat religius keagamaan yang berhubungan dengan kepercayaan kepada Tuhan dan kepada tete-nenek moyang yang memberikan atau menetapkan peraturan itu.

Ikatan pela dibentuk dengan sumpah setia dan diikat dengan serangkaian peraturan yang kuat sekali dan harus ditaati antara lain : dilarang melakukan tindakan-tindakan kekerasan dan pembunuhan antara sesama pela, harus saling membantu dalam keadaan kritis seperti ekonomi, dan pembangunan proyek-proyek tertentu, saling menerima dan saling melayani sebagai saudara sendiri bila dikunjungi serta terdapat larangan untuk tidak kawin mengawini antara warga sepela untuk jenis-jenis pela tertentu. $^{6}$

Terhadap serangkaian peraturanperaturan sebagaimana disebutkan diatas maka masyarakat desa dalam suku Alune

\footnotetext{
${ }^{6}$ Titaley Mesak., 1988, Pela sebagai sarana perjumpaan Islam Kristen di Maluku (Skripsi), Fakultas Filsafat Theologia UKIM, Ambon, h. 36.
} 
dan Wemale yang menganut ikatan pela darah, umumnya menganggap sakral untuk melanggar ketentuan tersebut karena dapat membawa bencana bagi hidup mereka sehingga suatu pelanggaran yang dilakukan dianggap merusak keseimbangan masyarakat persekutuan hukum dan juga merasa bersalah terhadap diri sendiri, terhadap Tuhan dan terhadap tete-nenek moyang (para leluhur). Dengan demikian dapat dikatakan bahwa pelanggaran terhadap adat pela secara tidak langsung merupakan pelanggaran terhadap delik adat.

Delik adat itu adalah semua perbuatan atau keadilan yang bertentangan dengan kepatutan, kerukunan, ketertiban, keamanan, rasa keadialan, dan kesadaran hukum masyarakat bersangkutan. ${ }^{7}$

Disisi lain delik adat didefinisikan sebagai perbuatan sepihak dari seseorang atau kumpulan perseorangan, mengancam atau menyinggung atau mengganggu keseimbangan dan kehidupan persekutuan bersifat material atau inmaterial terhadap orang seorang atau terhadap masyarakat berupa kesatuan. ${ }^{8}$ Terkait dengan kontribusi pela tersebut, berikut ini akan dijelaskan beberapa hal yang sangat

\footnotetext{
7 Hilman Hadikusuma., 1978, Hukum Adat, Alumni, Bandung, h. 20

${ }^{8}$ I Made Widnyana, 1992, Eksistensi Delik Adat Dalam Pembangunan, Orasi Pengukuhan Jabatan Guru Besar Tetap Dalam Ilmu Hukum Pidana Pada Fakultas Hukum Universitas Udayana, h. 5.
}

mendasar dari pela itu sendiri, yang antara lain meliputi :

\section{Pengertian Pela}

Istilah pela yang terdapat di daerah Maluku masih belum diketahui dengan pasti dari mana asal daerahnya dan asli bahasanya. Ada yang mengatakan dari Seram, dan ada juga yang mengatakan dari Melanesia atau fasifik selatan.

Dalam sejarah pela Tihulale dan Hukuanakota maupun Rambatu dan Abio, pada hakekatnya mengartikan pela menurut arti kata bahasa Alune, Pela berarti "sudah dan habis". Ini mempunyai pengertian bahwa sagala yang terjadi pada masa lampau, terkait dengan peperangan dan pembunuhan, marilah kita sudahi dan kita habiskan sampai disini dan diantara kita tidak boleh lagi ada perkelahian, peperangan dan pembunuhan.

\section{Sejarah Terbentuknya Pela}

Dari segi sejarah dikenal adanya dua suku di pulau Seram, yakni suku "Alune dan Wemale". Kedua suku ini umumnya menempati wilayah seram bagian barat dan seram bagian utara. Desadesa di wilayah seram bagian barat dan seram bagian utara. Desa-desa di Seram Bagian Barat yang masuk klasifikasi dua suku ini, diantaranya desa "Tihulale, Hukuanakota, Rambutan dan Abio”. Dari keempat desa tersebut, tiga diantaranya 
berasal dari suku Alune sedangkan desa Abio sendiri berasal dari suku Wemale. Perbedaan mendasar antara kedua suku ini terletak pada bahasa yang digunakan.

Kilas balik tentang bagaimana terbentuknya hubungan pela antara desa Tihulale dan desa Hukuanakota, maupun desa Rambatu dan desa Abio, tidak bisa dilepas-pisahkan dari kehidupan orangorang Alune dan Wemale pada masa lampau. Salah satu sisi kehidupan dari kedua suku ini adalah berperang.

Masyarakat tradisional yang hidup pada saat itu berada dalam kehidupan yang kacau balau, dimana setiap saat terjadi peperangan dan pembunuhan antar kelompok, baik antar Suku Alune dan Alune. Wemale dengan Alune, maupun Wemale dengan Wemale.

Ketika penyebaran agama Kristen ke Maluku dan masuk ke seram bagian barat, kondisi orang-orang Alune dan Wemale mulai mengalami pergeseran nilai dari kehidupan mereka yang lazim ke kehidupan yang lebih bersahabat. Disini pela mulai dirintis dan mulai dibangun antara desa-desa dalam Suku "Alune dan Wemale" lebih khusus bagi keempat desa tersebut. Pada tahun 1940 desa Rambatu dan desa Abio resmi mengangkat pela, menyusul tahun 1942 desa Tihulale dan desa Hukuanakota.

Dalam angkat pela tersebut, masyarakat dari masing-masing negeri atau desa saling mengangkat sumpah bahwa "mulai dari saat ini dan detik ini di antara kita tidak ada lagi perkelahian dan pembunuhan". Sumpah tersebut kemudian dikukuhkan secara adat di Baileo dimana masyarakat dari masing-masing negeri atau desa saling meminum air sumpahan yang terbuat dari tuak dan darah ayam jantan putih yang sudah diramu sedemikian rupa, sebagai pengganti darah manusia. Setelah upacara adat selesai sumpah diikat dengan doa dengan suatu ibadah pendek di gereja. Pela ini kemudian oleh masyarakat disebut sebagai Pela Darah.

Konsekuensi logis dari pengangkat pela tersebut, melahirkan beberapa aturan atau norma berupa larangan dan anjuran yang harus diingat, dipatuhi dan tidak boleh dilanggar oleh kedua negeri yang berpela. Larangan dan anjuran itu meliputi beberapa hal antara lain :

a. Sesama pela dilarang untuk tidak saling melontarkan kata-kata tajam, berupa makian atau sejenisnya yang sifatnya menimbulkan perasaan tidak enak bagi pela yang lain.

b. Dilarang untuk tidak saling berkelahi, membunuh dan mengawini antar sesama pela.

c. Dianjurkan untuk sesama pela tetap saling melayani dalam waktu susah ataupun senang, tidak boleh saling menyembunyikan apa saja yang sifatnya dimakan dari sesama pela. 
Pelanggaran terhadap ketentuanketentuan tersebut akan mendapat kutukan dari Tuhan dan dari para leluhur yang menjurus pada penderitaan dan kematian. Larangan dan anjuran yang sudah disepakati bersama, sifatnya mengikat dan tidak dapat diganggu gugat oleh siapapun.

\section{Karakteristik Pela}

Menurut jenisnya pela dibedakan atas dua macam yaitu pela dara dan pela tempat sirih. Komunitas warga yang menganut pela dara ini dilarang untuk tidak saling mengawini, sedangkan untuk pela tempat sirih warga yang berpela itu diperbolehkan untuk saling mengawini. Sedangkan pada bagian lain pela juga di bagi atas tiga bagian masing-masing "pela keras atau pela tuni termasuk didalamnya pela tumpah darah atau pela batu karang, pela gadong dan pela tempat sirih". ${ }^{9}$

Dari berbagai jenis pela sebagaimana dikemukakan diatas, maka bagi masyarakat "Tihulale, Hukuanakota, Rambatu dan Abio", mereka hanya mengenal 2 (dua) jenis pela yaitu pela darah dan pela tempat sirih. Namun jenis pela yang dianut oleh keempat Desa tersebut adalah pela darah.

\section{Mempertahankan Norma Pela}

\footnotetext{
9 Anonymous, 1989, Tata Pergaulan di Lingkungan Pergaulan Keluarga dan Masyarakat Daerah Maluku, Departemen Pendidikan dan Kebudayaan, h. 29.
}

Dalam kemajuan ilmu pengetahuan dan teknologi dewasa ini, kadang masyarakat diperhadapkan dengan berbagai perkembangan baru, baik dalam segi ekonomi, sosial budaya dan hukum. Dengan perkembangan tersebut, apakah nilai-nilai adat itu kemudian ikut terkikis ataukah tetap dipertahankan. Hal ini tentu dikembalikan pada prilaku masyarakat dimana aturan atau norma adat itu diberlakukan.

Perilaku dan pendirian masyarakat terhadap aturan atau norma pela yang mereka anut menunjukan bahwa sampai saat ini mereka masih tetap mempertahankan aturan dan norma tersebut. Mereka pada prinsipnya beranggapan bahwa dengan dipertahankannya aturan dan norma tersebut maka kehidupan masyarakat dari waktu kewaktu tetap hidup dengan aman, tertib dan damai tanpa suatu gejolak apapun diantara mereka. Perilaku demikian tentu memberikan kontribusi yang sangat berarti untuk mencegah masyarakat dari tindakan yang sifatnya bertentangan dengan sendi-sendi kehidupan berpela.

\section{Pelanggaran Norma Pela}

Penataan kehidupan suatu masyarakat dengan aturan-aturan hukum seketat apapun, pasti saja ada pelanggaranpelanggaran yang dibuat. Namun demikian aturan-aturan itu tetap harus ada dalam 
masyarakat guna menekan atau mengeliminir sekecil mungkin timbulnya gejolak dalam masyarakat.

Hingga kini pelanggaran terhadap aturan dan larangan dalam hubungan pela sudah sering terjadi.

\section{Sangsi Terhadap Pelanggaran Pela}

Sanksi dalam hubungan pela biasanya dibedakan atas 2 (dua) bagian yaitu sanksi yang kelihatan dan sanksi yang tidak kelihatan. Sanksi yang kelihatan biasanya dilakukan oleh fungsionaris hukum adat, seperti "Badan Saniri Negeri". Sedangkan sanksi yang tidak kelihatan biasanya datang dari Tuhan dan para leluhur yang dipercayai masyarakat yang dikenal sebagai pembentuk pela. Kedua sanksi ini dikenal juga dalam hubungan pela antara Desa "Tihulale dan Hukuanakota" maupun Rambatu dan Abio. Namun yang lebih banyak terjadi adalah sanksi yang tidak kelihatan.

Bentuk sanksi yang tidak kelihatan itu berbentuk seperti "Guntur, kilat, angin rebut dan hujan serta penyakit". Sanksi ini oleh masyarakat setempat dianggap sebagai kutukan Tuhan dan kutukan dari para leluhur atau tete nenek moyang. Apabila kondisi ini tidak dikembalikan ke keadaan semula, maka hal ini bisa berakibat kematian. Sanksi ini muncul ketika ada sesuatu yang tidak beres antara kedua negeri yang berpela, misalnya pelanggaran terhadap butir-butir kesepakatan yang terdapat dalam aturan atau norma-norma pela.

Dalam sejarah pela Desa "Tihulale, Hukuanakota, Rambatu dan Abio, sanksi tersebut sudah sering terjadi. Untuk menyelamatkan masyarakat dari sanksisanksi itu, maka pihak yang memulai konflik biasanya yang memohon agar secepatnya melakukan panas pela untuk membuat situasi kembali normal.

\section{B. Sarana Penyelesaian Konflik}

\section{Panas Pela}

Bila dikaji dari segi sejarah maka panas pela pada prinsipnya merupakan kelanjutan dari angkat pela. Hal ini merupakan manifestasi dari pemikiran masyarakat untuk selalu dan senantiasa menyiapkan sarana lain yang sifatnya bisa dijadikan sebagai sarana penyelesaian, mengantisipasi kemungkinan konflik yang terjadi antar desa atau negerinegeri yang berpela.

Panas pela merupakan sarana atau media baku dapa (bertemu) antar kedua negeri yang berpela untuk membicarakan dan menyelesaikan berbagai persoalan hidup diantara mereka demi untuk lebih mengokohkan hubungan-hubungan pela di antara mereka. Panas pela juga merupakan suatu kegiatan ritual 
masyarakat dan pada saat tertentu hal ini selalu dilaksanakan. Untuk desa Tihulale dan Hukuanakota, disepakati agar 4 (empat) tahun sekali dilaksanakan panas pela. Sedangkan untuk desa Rambatu dan Abio, panas pela dilakukan 3 (tiga) tahun sekali. Namun keputusan ini bisa saja berubah kalau ada permintaan dari salah satu pihak, terkait dengan persoalan-persoalan yang muncul dalam masyarakat.

\section{Alasan Panas Pela}

Alasan diadakannya panas pela tersebut adalah untuk menyelesaikan berbagai persoalan-persoalan yang terjadi, terkait dengan pelanggaranpelanggaran yang dibuat oleh kedua masyarakat. Lewat panas pela ini masyarakat didamaikan dan disatukan kembali untuk selalu dan senantiasa menjaga hubungan baik diantara mereka.

Panas pela bagi generasi muda dari kedua negeri perlu dilakukan untuk tetap menjaga apa yang sudah dibuat oleh leluhur mereka demi tercapainya ketertiban dan keamanan dalam masyarakat.

\section{Panas Pela Sebagai Sarana Penyelesaian Konflik}

Secara umum masyarakat Tihulale, Hukuanakota, Rambatu dan Abio telah menjadikan panas pela sebagai alat rekonsiliasi untuk menyelesaikan berbagai persoalan hidup yang terjadi diantara masyarakat yang berbeda. Hal ini cukup beralasan karena ketika ada konflik yang muncul, penyelesaiannya tidak mungkin lagi ditempuh melalui angkat pela. Dalam sejarah suku Alune dan Wemale, angkat pela hanya dilakukan sekali dalam kehidupan mereka. Dengan demikian untuk mengakomodir konflik akibat pelanggaran terhadap adat pela yang muncul diantara mereka, maka sarana yang dipergunakan untuk menyelesaikan persoalan tersebut hanyalah melalui panas pela, hal ini sangatlah sesuai dengan sistem hukum adat.

Dalam sistem hukum adat segala perbuatan yang bertentangan dengan peraturan hukum adat merupakan perbuatan illegal dan hukum adat mengenal ikhtiar-ikhtiar untuk memperbaiki kembali hukum, jika hukum itu diperkosa. ${ }^{10}$ Dengan demikian panas pela merupakan bagian dari sistem hukum adat.

\footnotetext{
${ }^{10}$ R. Soepomo., 1977, Bab-bab Tentang Hukum Adat,
} Pradnya Paramita, Jakarta, h. 110. 


\section{PENUTUP}

\section{A. Kesimpulan}

$>$ Angkat pela dan panas pela pada hakekatnya merupakan 2 (dua) sarana penting yang selama ini memberikan kontribusi yang berarti dalam menyelesaikan berbagai konflik yang timbul dalam masyarakat Maluku.

$>$ Melalui angkat pela dan panas pela, masyarakat dari kedua desa atau negeri menemukan jati dirinya untuk selalu memelihara dan menjaga ketertiban dan keamanan dalam masyarakat.

\section{B. Saran}

Sangat penting bagi masyarakat Maluku sekarang untuk tetap melestarikan budaya pela agar hubungan persaudaraan dan kekeluargaan tetap bertahan. Oleh karena itu perlu mengefektifkan kembali panas pela paling tidak untuk setiap generasi.

$>$ Dalam rangka memperkaya khasana hukum nasional maka dipandang perlu untuk hukum adat dalam bentuk hubungan pela tetap dipertahankan sebagai bentuk hukum yang hidup dalam masyarakat karena sangat bermanfaat demi pengembangan hukum nasional ke depan. 


\section{DAFTAR BACAAN}

Anonymous, 1989, Tata Pergaulan di Lingkungan Pergaulan Keluarga dan Masyarakat Daerah Maluku. Departemen Pendidikan Dan Kebudayaan.

F.L. Cooley, 1987, Mimbar dan tahta (Hubungan Lembaga-lembaga Keagamaan dan Pemerintahan di Maluku Tengah). Pustaka Sinar Harapan Jakarta. ,1902, Altar And Thome in Central Molucan Societies. Yale Univ.

Hilman Hadikusuma., 1978, Hukum Adat, Alumni, Bandung.

I Made Widnyana, 1992, Eksistensi Delik Adat Dalam Pembangunan, Orasi Pengukuhan Jabatan Guru Besar Tetap Dalam Ilmu Hukum Pidana Pada Fakultas Hukum Universitas Udayana.

Mahadi, Monografi Hukum Adat. Binacipta.

Pieter Tanamal, Pengabdian Dan Perjuangan.

R. Soepomo., 1977, Bab-bab Tentang Hukum Adat, Pradnya Paramita, Jakarta.

Soejomo Soekanto, Pokok-pokok Sosiologi Hukum.

Titaley. Mesak, 1988, Pela Sebagai Sarana Perjumpaan Islam-Kristen Di Maluku (Skripsi), Fakultas Filsafat Theologi UKIM, Ambon. 


\section{BIODATA PENULIS}

Nama $\quad$ : Steven Makaruku. SH.

Alamat Rumah : Jl. Dr. Kayadoe Kudamati - Ambon

Pekerjaan : Dosen/ PNS

Tempat Bekerja : Fakultas Hukum - Universitas Pattimura Ambon.

Hp : : 081353299097

Alamat e-mail : - 